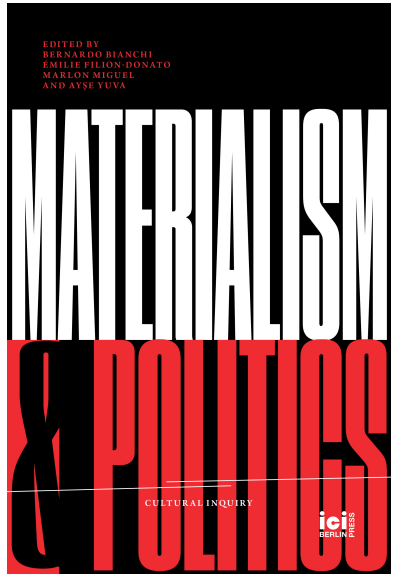

Materialism and Politics, ed. by Bernardo $\mathrm{Bi}$ anchi, Emilie Filion-Donato, Marlon Miguel, and Ayşe Yuva, Cultural Inquiry, 20 (Berlin: ICI Berlin Press, 2021), pp. 271-76
DANIEL LIU (D)

\section{Introduction to Part IV}

\author{
CITE AS:
}

Daniel Liu, 'Introduction to Part Iv', in Materialism and Politics, ed. by Bernardo Bianchi, Emilie Filion-Donato, Marlon Miguel, and Ayşe Yuva, Cultural Inquiry, 20 (Berlin: ICI Berlin Press, 2021), pp. 271-76 <https://doi.org/10.37050/ci-20_004>

\section{RIGHTS STATEMENT:}

(C) by the author(s)

Except for images or otherwise noted, this publication is licensed under a Creative Commons Attribution-ShareAlike 4.0 International License. 


\section{Introduction to Part IV}

DANIEL LIU

The following five chapters are varying attempts to reassemble the 'historical' and the 'materialist' constituents of the history of materialism on terms which are not those of the 'historical materialism' that was mandated by Marxist and Leninist orthodoxy for much of the twentieth century. ${ }^{1}$ This part begins with Frieder Otto Wolf's call to pay closer attention to what Karl Marx (1818-1883) was trying to articulate under the heading 'the materialist conception of history', in order to dissolve a calcified version of historical materialism from the twentieth century. Wolf emphasizes that Marx's project was one of theory building, and calls attention to Raúl Rojas' argument that Marx's so called 'historical materialism' was an 'unfinished project' and should not, therefore, be read as scripture or commandment. ${ }^{2}$ In place of an overarching theory of a law-like succession of social orders of production, Wolf argues that a methodological 'finite Marxism' should focus on the specific details of how contemporary capitalism actually operates, and how it produces its unique patterns of power and domination.

The part then moves on to the contributions by Ayşe Yuva and Alex Demirović, which provide distinctly opposing claims about the

1 Tony Judt, 'Goodbye to All That?', New York Review of Books, 1111.14 (21 September 2006).

2 Raúl Rojas, Das unvollendete Projekt: Zur Entstehungsgeschichte von Marx' Kapital, Philosophie und Sozialwissenschaften, 14 (Berlin: Argument, 1989). 
relationship between materialist philosophy and political philosophy. Yuva's chapter returns to the eighteenth century to provide broader historical and geographical contexts for the history of materialist philosophy, paying particular attention to the ways in which materialism has been attacked for being 'reductionist', 'vulgar', or too 'mechanical'. Yuva argues that this blanket critique needs to be counterbalanced with the actual historical contexts in which materialism was adopted in the eighteenth and nineteenth centuries: namely, that materialism was explicitly articulated as alternatives to philosophies based on incorporeal ideals or 'spirit', and in opposition to the theologies and theocracies that used to dominate the world's major political orders. In particular, Yuva explores Germaine de Staël's (1766-1817) influential argument about the opposing tendencies of English materialism vs German idealism, and largely maps this binary opposition to the Ottoman political reformer Beşir Fuad (1852-1887), who adopted the mantle of scientific materialism in order carve out a philosophical space independent of conservative Islamic orthodoxy. On the other hand, Demirović marshals two of the dominant French philosophers of the twentieth century, Michel Foucault (1926-1984) and Louis Althusser (1918-1990), to augment Marx and to argue that 'politics is really a kind of spiritualism and it is illusory. ${ }^{3}$ In this way, Demirović can argue that his own so-called 'critical materialism' is 'concerned with the reality of ghosts and the undead precisely because the political mind is spiritual, and because the economy is theological and metaphysical. ${ }^{4}$ It is unclear if there is any middle ground between Demirović's conclusion and Yuva's appeal that we 'not fall back into a dogmatic materialism, unconscious of the ideological parts it inherited from its history'.

The last two chapters in the section elaborate some of the essential ground for Demirović's claims. The contribution by Facundo Vega is a close reading and critique of the oeuvre of the leftist political philosopher Ernesto Laclau (1935-2014), in particular Laclau's attempt to juggle the political importance of Marxist historical materialism in the mid-twentieth century with a Heidegger-inflected, post-structuralist

3 Demirović, in this volume, p. 323.

4 Ibid., p. 325. 
anti-foundationalism. Vega tracks the development of Laclau's thought from the late-1970s to his death in 2014, showing how Laclau's earlier, Marxist arguments about class conflict and modes of production in the 1980s gave way to meditations on the ontological foundation of 'the political' in the 1990s. The end result of Laclau's recourse to 'the political' in the metaphysical sense is, according to Vega, a totalizing conception of political difference, one that elides into populism and proto-fascism.

Vega's critique of Laclau's attempt to cast politics in purely metaphysical terms is complemented by Marianna Poyares's chapter on the salutary uses of ethnography in critical social theory. Poyares argues that the ethnographic method itself calls attention to positionality, difference, and plurality, starting with the explicit need to clarify the relationship between actors' and analysts' categories. For Poyares this self-reflection itself constitutes 'bringing the theorist closer to "matter itself"', 5 primarily by forcing the theorist to question and re-examine the hegemony of her prior theoretical categories.

To round out this introduction, I would like to call attention to a dual use of 'materialism' in these five contributions.

1. The first is the problem of which philosophers or what kinds of philosophy are considered to be 'materialist', either by their contemporaries at the time or by later philosophers in retrospect. This is essentially a problem of distinguishing materialist philosophy from other, presumably non-materialist philosophies. For the moment, let us call this 'materialism 1 '.

2. The second is the problem of what kinds of materials or things such materialist philosophers hold as central or prototypical to their understanding of why materialism, as a general set of philosophical positions, ought to be taken more seriously than other, non-materialist philosophies. Let's call this 'materialism ${ }_{2}$ '.

We might initially construe materialism 2 ('What materials are materialists concerned with?') to be a subset of materialism 1 ('What is materialism?'), therefore making materialism $\mathrm{m}_{1}$ the bigger and more important problem area to address. However, Yuva's chapter in particular 
calls attention to the fact that the moniker 'materialism' in its various guises was also a way to harness growing natural and social 'scientific' knowledge of materials and material relations in order to challenge the theologies and theocracies that used to dominate the world's major political orders. Materialism, so its protagonists claimed, insisted upon the primary importance of the material, the substantive, and ultimately secular world, over and against the ideal and the spiritual. ${ }^{6}$ Another way to put it: a key hallmark of materialist philosophy is that it insists that materialism ${ }_{2}$ is more important than materialism ${ }_{1}$, because materialists argue that the totality and variety of material relations supersedes idealist or metaphysical presumptions.

Notice the repeated invocations of the particular and the specific against the general and the abstract in these five chapters on historical materialism. In Wolf's chapter, we see (emphases mine):

According to this analysis, finite Marxism combines a specific analysis and reconstruction of the domination of the capitalist mode of production $[\ldots]^{7}$

The project of laying bare the inner workings, structures, mechanisms, and tendencies of the domination of the capitalist mode of production in modern bourgeois societies, and at least to begin to understand how they present themselves in actual lived experience, has not been entirely lost, in spite of many simplifications and reductionist tendencies $[\ldots]^{8}$ this field of scientific research $[\ldots]$ insights into the actual workings of the historical domination of the capitalist mode of production. ${ }^{9}$

Finite Marxism [ ... ] is uniquely capable of understanding the 'specific materiality and the characteristic conditions' of other fields of domination. ${ }^{10}$

not $[\ldots]$ by offering 'Marxism' as an overarching theory, but by emphasizing its own specific contribution $[\ldots]^{11}$

$[\ldots]$ without attempting to subsume them to Marxist generalities $[\ldots]^{12}$

\footnotetext{
6 Margaret C. Jacob, The Secular Enlightenment (Princeton, NJ: Princeton University Press, 2019).

7 Wolf, in this volume, p. 280.

8 Ibid., p. 285.

9 Ibid., p. 286.

$10 \quad$ Ibid., p. 289.

11 Ibid., p. 290.

12 Ibid.
} 
In Poyares's argument for the uses of ethnography (again, emphases mine) via Robin Celikates:

Critique has to be based on the analysis of social reality and its contradictions, and $[\ldots]$ can only find its criteria in the social practices, struggles, experiences, and self-understandings to which critique is connected. ${ }^{13}$

$[\ldots]$ empirical research without the reduction of the object of analysis to the mere instantiation of theory $[\ldots]^{14}$

And in his critique of Ernesto Laclau's latter-day populism, Vega argues that Laclau's 'operation of de-substantializing and re-substantializing "the people" leads to a disdain for the autonomy of "the many"' (again, emphasis mine). ${ }^{15}$ Notice that, time and again in all but one of these chapters, the philosophers being studied and the authors of the essays themselves align 'materialism' with specificities, and hold 'reality', 'objects', 'inner workings', 'the many', and the manifold lived experiences against theory and generalities. If Platonism and Heideggerian ontology progressively abstract their way towards the Good, or the One, or to God, or Being itself, ${ }^{16}$ then materialism moves in the opposite direction. ${ }^{17}$ It should therefore not be a surprise that, since the eighteenth century, the natural sciences provided the empirical foundation of and inspiration for modern materialist philosophy against both theology and metaphysical speculation. Additionally, it must be observed that

13 Poyares, in this volume, p. 347.

14 Ibid., p. 350.

15 Vega, in this volume, p. 339.

16 That is to say, the operation Heidegger is engaged in is not so dissimilar to Plato and Plotinus. See Benjamin Crowe, Heidegger's Religious Origins: Destruction and Authenticity (Bloomington: Indiana University Press, 2006); Hans Jonas, 'Gnosticism and Modern Nihilism', Social Research, 19.4 (December 1952), pp. 430-52; Benjamin Lazier, God Interrupted: Heresy and the European Imagination Between the World Wars (Princeton, NJ: Princeton University Press, 2009); Karl Löwith, 'Knowledge and Faith: From the Pre-Socratics to Heidegger', in Religion and Culture: Essays in Honor of Paul Tillich, ed. by Walter Liebrecht (New York: Harper, 1959), pp. 196-210. In George Steiner's introductory text Martin Heidegger (Chicago: University of Chicago Press, 1991), Steiner objects that, although one could interpret Heidegger as a cryptoPlatonist, Heidegger himself rejects this (pp. 60-61). However, one should actually examine how Heidegger does this, rather than simply accept his own interpretation as doctrine.

17 Hans Blumenberg makes a parallel argument about the history of creativity in "'Imitation of Nature": Toward a Prehistory of the Idea of the Creative Being', trans. by Anna Wertz, Qui Parle, 12.1 (2000), pp. 17-54. 
debates about the relationship between the general and the particular were most robustly practiced in the natural and social sciences. ${ }^{18}$

This vast diversity in our material environments is precisely why so many of the 'New Materialists' from the early-2000s found references to the natural sciences so valuable, if fraught. But, as Poyares argues quite forcefully, one need not go all the way to the natural sciences to find challenging materials in their particularities: the social and political sciences, which are the home of the ethnographic method, give plenty of examples.

18 Lynn K. Nyhart, 'Wissenschaft and Kunde: The General and the Special in Modern Science', Osiris, 27.1 (2012), pp. 250-75 <https://doi.org/10.1086/667830>; Lynn K. Nyhart, 'The Political Organism: Carl Vogt on Animals and States in the 1840s and '50s', Historical Studies in the Natural Sciences, 47.5 (November 2017), pp. 602-28 <https://doi.org/10.1525/hsns.2017.47.5.602>; Sander Gliboff, H. G. Bronn, Ernst Haeckel, and the Origins of German Darwinism: A Study in Translation and Transformation (Cambridge, MA: MIT Press, 2008); Sabina Leonelli, Data-Centric Biology: A Philosophical Study (Chicago: University of Chicago Press, 2016); Horst W. J. Rittel and Melvin M. Webber, 'Dilemmas in a General Theory of Planning', Policy Sciences, 4.2 (June 1973), pp. 155-69; Charles H. Pence, "'Describing Our Whole Experience": The Statistical Philosophies of W. F. R. Weldon and Karl Pearson', Studies in History and Philosophy of Biological and Biomedical Sciences, 42.4 (2011), pp. 47585 <https://doi.org/10.1016/j.shpsc.2011.07.011>; Theodore M. Porter, Genetics in the Madhouse: The Unknown History of Human Heredity (Princeton, NJ: Princeton University Press, 2018). See also Wilhelm Windelband, 'Rectoral Address, Strasbourg, 1894', History and Theory, 19.2 (February 1980), pp. 169-85 <https://doi.org/10. 2307/2504798>. 
Daniel Liu, 'Introduction to Part Iv', in Materialism and Politics, ed. by Bernardo Bianchi, Emilie Filion-Donato, Marlon Miguel, and Ayşe Yuva, Cultural Inquiry, 20 (Berlin: ICI Berlin Press, 2021), pp. 271-76<https://doi.org/10.37050/ci-20_004>

\section{REFERENCES}

Blumenberg, Hans, "Imitation of Nature": Toward a Prehistory of the Idea of the Creative Being', trans. by Anna Wertz, Qui Parle, 12.1 (2000), pp. 17-54

Crowe, Benjamin, Heidegger's Religious Origins: Destruction and Authenticity (Bloomington: Indiana University Press, 2006)

Demirović, Alex, 'The Historicity of Materialism and the Critique of Politics', in Materialism and Politics, ed. by Bernardo Bianchi, Emilie Filion-Donato, Marlon Miguel, and Ayşe Yuva, Cultural Inquiry, 20 (Berlin: ICI Berlin Press, 2020), pp. 313-26 <https: / doi.org/ $10.37050 /$ ci-20 17>

Gliboff, Sander, H. G. Bronn, Ernst Haeckel, and the Origins of German Darwinism: A Study in Translation and Transformation (Cambridge, MA: MIT Press, 2008) <https://doi.org/ 10.7551/mitpress/9780262072939.001.0001>

Jacob, Margaret C., The Secular Enlightenment (Princeton, NJ: Princeton University Press, 2019)

Jonas, Hans, 'Gnosticism and Modern Nihilism', Social Research,19.4 (December 1952), pp. $430-52$

Judt, Tony, 'Goodbye to All That?', New York Review of Books, 1111.14 (21 September 2006)

Lazier, Benjamin, God Interrupted: Heresy and the European Imagination Between the World Wars(Princeton, NJ: Princeton University Press, 2009) <https://doi.org/10.1515/ 9781400837656>

Leonelli, Sabina, Data-Centric Biology: A Philosophical Study (Chicago: University of Chicago Press, 2016) <https://doi.org/10.7208/chicago/9780226416502.001.0001>

Löwith, Karl, 'Knowledge and Faith: From the Pre-Socratics to Heidegger', inReligion and Culture: Essays in Honor of Paul Tillich, ed. by Walter Liebrecht (New York: Harper, 1959), pp. 196-210

Nyhart, Lynn K., 'The Political Organism: Carl Vogt on Animals and States in the 1840s and '50s', Historical Studies in the Natural Sciences, 47.5 (November 2017), pp. 602-28 <https://doi.org/10.1525/hsns.2017.47.5.602>

'Wissenschaft and Kunde: The General and the Special in Modern Science', Osiris, 27.1 (2012), pp. 250-75 <https://doi.org/10.1086/667830>

Pence, Charles H., “'Describing Our Whole Experience”: The Statistical Philosophies of W. F. R. Weldon and Karl Pearson', Studies in History and Philosophy of Biological and Biomedical Sciences, 42.4 (2011), pp. 475-85 <https://doi.org/10.1016/j.shpsc.2011.07.011>

Porter, Theodore M., Genetics in the Madhouse: The Unknown History of Human Heredity (Princeton, NJ: Princeton University Press, 2018) <https://doi.org/10.23943/ 9781400890507>

Poyares, Marianna, 'Theory's Method?: Political Ethnography and Critical Social Theory', in Materialism and Politics, ed. by Bernardo Bianchi, Emilie Filion-Donato, Marlon Miguel, 
and Ayşe Yuva, Cultural Inquiry, 20 (Berlin: ICI Berlin Press, 2020), pp. 345-63 < https: //doi.org/10.37050/ci-20_19>

Rittel, Horst W. J., and Melvin M. Webber, 'Dilemmas in a General Theory of Planning', Policy Sciences, 4.2 (June 1973), pp. 155-69 <https://doi.org/10.1007/BF01405730>

Rojas, Raúl, Das unvollendete Projekt: Zur Entstehungsgeschichte von Marx' Kapital, Philosophie und Sozialwissenschaften, 14 (Berlin: Argument, 1989)

Steiner, George, Martin Heidegger (Chicago: University of Chicago Press, 1991)

Vega, Facundo, 'On Populist Illusion: Impasses of Political Ontology, or How the Ordinary Matters', in Materialism and Politics, ed. by Bernardo Bianchi, Emilie Filion-Donato, Marlon Miguel, and Ayşe Yuva, Cultural Inquiry, 20 (Berlin: ICI Berlin Press, 2020), pp. 327-43 <https://doi.org/10.37050/ci-20_18>

Windelband, Wilhelm, 'Rectoral Address, Strasbourg, 1894', History and Theory, 19.2 (February 1980), pp. 169-85 <https://doi.org/10.2307/2504798>

Wolf, Frieder Otto, 'Materialism against Materialism: Taking up Marx's Break with Reductionism', in Materialism and Politics, ed. by Bernardo Bianchi, Emilie Filion-Donato, Marlon Miguel, and Ayşe Yuva, Cultural Inquiry, 20 (Berlin: ICI Berlin Press, 2020), pp. 277-92 <https://doi.org/10.37050/ci-20_15>

Yuva, Ayşe, 'Materialism, Politics, and the History of Philosophy: French, German, and Turkish Materialist Authors in the Nineteenth Century', in Materialism and Politics, ed. by Bernardo Bianchi, Emilie Filion-Donato, Marlon Miguel, and Ayşe Yuva, Cultural Inquiry, 20 (Berlin: ICI Berlin Press, 2020), pp. 293-312<https://doi.org/10.37050/ci20_16> 